\title{
Serum C-Reactive Protein in Nigerians With Type 2 Diabetes Mellitus
}

\author{
*Baba MM, **Kolawole BA, **lkem RT, **Arogundade FA, "Yusuph $H,{ }^{*}$ Gezawa ID \\ *Department of Medicine University of Maiduguri Teaching Hospital Borno State Nigeria. \\ ${ }^{* * D}$ epartment of Medicine Obafemi Awolowo University lle-Ife Osun State Nigeria.
}

\begin{abstract}
Background: C-reactive protein is an acute-phase proteins, produce in the liver, its release is stimulated by cytokines (interleukin 6 and tumournecrosis factor alpha). Elevated level of it is a risk factor for coronary heart disease. Baseline levels of $\mathrm{C}$-reactive protein in apparently healthy men and women predict long-term risk of a first myocardial infarction. Diabetics are at increased risk for coronary heart disease, data from the Framingham Study showed a two-to three-fold elevation in the risk of clinically evident atherosclerotic disease in patients with type II diabetes compared to those without diabetes. However, but data regarding CRP in Nigerian diabetic is lacking.
\end{abstract}

Method: A cross-sectional study conducted among patients attending out patient clinic of the Obafemi Awolowo University Teaching Hospitals complex (OAUTHC) Ile Ife, Osun State south western Nigeria. Measurement of C-reactive protein was based on the principle of solid phase enzyme-linked immunosorbent assay (ELISA).

Results: A total of 125 consecutive subjects were recruited comprising 75 patients with type II diabetes mellitus with or without hypertension and 50 apparently healthy age-and-sex comparable controls. There was a significant difference between the mean systolic and diastolic blood pressures of the patients and controls. The fasting blood glucose and C-reactive protein were significantly higher in diabetics compared to controls. There was a positive and significant correlation between $F B G$ and $C R P$ in both patients and controls.

Conclusion: This study showed that diabetics have significantly higher serum C-reactive protein compared to the apparently controls. Also there was a positive and significant correlation between C-reactive protein and fasting blood glucose among both patients and controls.

\footnotetext{
Date Accepted for Publication: $10^{\text {th }}$ May 2010

NigerJMed 2010: 427 - 431

Copyright@ 2010 Nigerian Journal of Medicine
}

\section{Introduction}

C- reactive protein was first identified by Tilet and Francis in1930 in the plasma of patients with pneumonia and was named for its ability to bind and precipitate the capsular polysaccharide of pneumococcus. ${ }^{1}$ It is synthesized in the liver and is normally present as a trace constituent of serum or plasma at levels less than $0.25-1.5 \mu \mathrm{g} / \mathrm{ml} .{ }^{2}$ Studies have shown that elevated levels of CRP is a risk factor for coronary heart disease (CHD). ${ }^{4-6}$ Baseline levels of CRP in apparently healthy men and women predict long-term risk of a first myocardial infarction. ${ }^{5}$ In older men and women, elevated CRP was found to be associated with a 10-year risk of CHD regardless of the presence or absence of cardiac risk factors. ${ }^{6}$ A single CRP measurement provides information beyond conventional risk assessment, especially in the intermediate Framingham risk men and high Framingham risk women. ${ }^{6}$ Elevated CRP levels have also been linked to an increased risk of later development of diabetes mellitus. ${ }^{7}$

Diabetics are at increased risk for $\mathrm{CHD}$, data from the Framingham Study showed a two-to three-fold elevation in the risk of clinically evident atherosclerotic disease in patients with type II diabetes compared to those without diabetes. ${ }^{8}$ Diabetic men in the Multiple Risk Factor Intervention Trial (MRFIT) study had an absolute risk of $\mathrm{CHD}$ death more than three times higher than that in the non-diabetic cohort, even after adjustment for established risk factors. ${ }^{9}$ National cholesterol education program considers diabetes mellitus to be a CHD equivalent in their lipid guideline. ${ }^{10}$ Diabetic patients with no history of CHD have the same risk for future myocardial infarction as do non-diabetic patients with known CHD. ${ }^{11}$ Diabetes eliminates the usual female advantage in the risk of death from CHD, as these patients have a 5-8 fold higher death rate than do non-diabetic women. ${ }^{12}$ Several proposed pathophysiologic mechanisms are implicated in the pathogenesis of vascular disease in diabetes mellitus. These include endothelial dysfunction, diabetic 
dyslipidaemia, hypercoagulability, impaired fibrinolysis, platelet hyperaggregability, oxidative stress and toxic effects of hyperglycaemia. ${ }^{13}$

However study regarding C-reactive protein in Nigerian diabetics is lacking hence decision to carry out this study to find out the relationship between C-reactive and diabetes mellitus in our population.

\section{Materials and Methods}

The study design was cross-sectional conducted among patients attending out patient clinic of the Obafemi Awolowo University Teaching Hospitals complex (OAUTHC) lle Ife, Osun State south western Nigeria. It comprised 75 consecutive patients with type II diabetes mellitus with or without hypertension and 50 apparently healthy age- and sex-comparable controls from the hospital staff and patient relatives who are themselves not relatives of the study patients were recruited. Using a structured pre-evaluated questionnaire, the demographic data, history of cigarette smoking, alcohol consumption, duration of diabetes, duration of hypertension were explored.

The diagnosis of diabetes mellitus was made on the basis of the reported history and medical records. Diabetic with chronic kidney disease, chronic liver disease, congestive cardiac failure or systemic infection were excluded from the study. Also excluded from the study were diabetics on oral contraceptive pills, analgesics or anti-inflammatory drugs and those on HMGcoA reductase inhibitor (statins). Diabetics aged less than eighteen years and those that did not consent were also excluded from the study. Ethical clearance was obtained from the ethics and research Committee of the Obafemi Awolowo University Teaching Hospitals Complex, and all participating subjects signed the informed consent form after being clearly explained to them. The following investigations were carried out: Fasting blood glucose and 2-hour post prandial, fasting lipid, serum electrolytes, urea and creatinine. Urinalysis was done using dip-stick while measurement of Creactive protein was based on the principle of solid phase enzyme-linked immunosorbent assay (ELISA).

\section{Data Analysis}

Data was presented as mean standard deviation (SD). Student t-test was used to test the significance of differences between mean values of continuous variables and Spearman's correlation coefficient was performed to determine the association between variables.
With statistical significance set at $p$ (probability) value less than 0.05. Tables and figures were used to present data, Statistical Package for Social Sciences version 11.0 (SPSS Chicago III. USA) was used for all statistical analysis.

\section{Results}

Demographic and clinical characteristics of the study population

A total of 125 consecutive subjects were recruited comprising 75 patients with type II diabetes mellitus with or without hypertension and 50 apparently healthy age-and-sex comparable controls. Forty-five (60.0\%) patients and $31(62.0 \%)$ controls were females with mean ages \pm SD of $57.2 \pm 9.4$ years and $56.6 \pm 7.8$ years, respectively $(p=0.804)$. Thirty $(40.0 \%)$ patients and $19(38.0 \%)$ controls were male with mean ages of $58.3 \pm 10.3$ years and $58.3 \pm 7.3$ years, respectively ( $p$ $=0.995$ ).

Body mass index differed significantly between patients and controls. The mean BMl of the patients and controls were $26.0 \pm 5.1 \mathrm{~kg} / \mathrm{m}^{2}$ and $21.9 \pm 1.6 \mathrm{~kg} / \mathrm{m}^{2}$, respectively $(p=0.000)$. Thirty $(40.0 \%)$ patients and $48(96.0 \%)$ controls had normal BMI $\left(18.5-24.9 \mathrm{~kg} / \mathrm{m}^{2}\right)$ (Fishers exact test, $p=0.000), 27(36.0 \%)$ patients and $2(4.0 \%)$ controls were overweight $\left(\mathrm{BMl}=25-29.9 \mathrm{~kg} / \mathrm{m}^{2}\right)$ (Fishers exact test, $p=0.000)$; while, $12(15.0 \%)$ patients were obese $\left(\mathrm{BMI}=30 \mathrm{~kg} / \mathrm{m}^{2}\right)$ and the remaining $6(8.0 \%)$ were underweight $\left(\mathrm{BMl}<18.5 \mathrm{~kg} / \mathrm{m}^{2}\right)$. The mean waist circumference of the female patients and controls were $92.5 \pm 10.0 \mathrm{~cm}$ and $81.5 \pm 2.7 \mathrm{~cm}$, respectively $(p=0.000)$. While male patients and controls had a mean waist circumference of $95.3 \pm 7.2$ $\mathrm{cm}$ and $92.8 \pm 2.4 \mathrm{~cm}$, respectively $(p=0.162)$.

Fifty-two $(69.3 \%)$ patients were hypertensive-diabetic and $23(30.7 \%)$ were normotensive-diabetic. Thirty-four $(65.38 \%)$ out of the 52 hypertensive-diabetic were females, while the remaining $18(34.61 \%)$ were males, while $50(100 \%)$ controls were apparently healthy subjects. The mean systolic blood pressure of the patients and controls were $144.0 \pm 12.2 \mathrm{mmHg}$ and $120.2 \pm 9.1 \mathrm{mmHg}$, respectively $(p=0.000)$, while the mean diastolic blood pressure were $87.1 \pm 8.0 \mathrm{mmHg}$ and $79.8 \pm 8.2 \mathrm{mmHg}$, respectively $(p=0.000)$.

Laboratory parameters of the study population

The mean fasting blood glucose of the patients was 9.3 
$\pm 2.4 \mathrm{mmol} / \mathrm{L}$ and was significantly higher than that of the controls $4.5 \pm 1.0 \mathrm{mmol} / \mathrm{L}(p=0.000)$. Patients had significantly higher than controls $2.5 \pm 0.5 \mu \mathrm{g} / \mathrm{mL}$ and 1.5 $\pm 0.4 \mu \mathrm{g} / \mathrm{mL}$, respectively $(p=0.000)$. The mean serum total cholesterol of the patients and controls were $5.7 \pm$ $1.3 \mathrm{mmol} / \mathrm{L}$ and $3.9 \pm 1.2 \mathrm{mmol} / \mathrm{L}$, respectively $(p=$ 0.000 ). While the serum LDL cholesterol of the patients and controls were $4.0 \pm 0.7 \mathrm{mmol} / \mathrm{L}$ and $2.1 \pm 0.4 \mathrm{mmol} / \mathrm{L}$, respectively $(p=0.000)$. There was a significant difference in the mean serum triglycerides between patients and controls $2.3 \pm 0.5 \mathrm{mmol} / \mathrm{L}$ and $1.4 \pm 0.2$ $\mathrm{mmol} / \mathrm{L}$, respectively. $(\mathrm{p}=0.000)$. Serum HDL cholesterol was significantly lower in patients compared to controls $0.9 \pm 0.2 \mathrm{mmol} / \mathrm{L}$ and $1.78 \pm 0.2 \mathrm{mmol} / \mathrm{L}$, respectively. $(p=$ 0.000 ).

There was a positive and significant correlation between FBG and CRP in both patients and controls $(r=0.656, p=$ $0.000)$ and $(r=0.551,(p=0.000)$ respectively. Similar correlations were also observed between CRP and BMI, CRP and systolic blood pressure, CRP and diastolic blood pressure in both patients and controls $(r=0.942, p$ $=0.000)$ and $(r=0.893, p=0.000),(r=0.667, p=0.000)$ and $(r=0.738, p=0.000),(r=0.438, p=0.000)$ and $(r=$ $0.686, p=0.000$ ), respectively. However, there was no significant correlation between the durations of hypertension and diabetes with CRP among the study patients $(r=0.135, p=0.251)$ and $(r=0.039, p=0.739)$ respectively.

On regression analysis, BMI, systolic blood pressure, diastolic blood pressure and FBG were significantly associated with CRP among patients (beta value $0.642, p$ $=0.000)$, (beta value $0.409, p=0.001)$, (beta $=0.162, p=$ 0.032 ) and (beta $=0.119, p=0.036$ ), respectively. Similarly, in the control group, BMl, systolic blood pressure, diastolic blood pressure, and FBG were

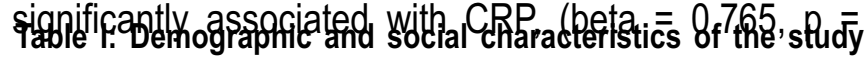
population.

$\begin{array}{llll}\begin{array}{l}\text { Parameters } \\ \text { Age } \\ \text { Male }\end{array} & \text { Patients } & \text { Controls } & \text { P-Value } \\ \text { Female } & 58.3 \pm 10.3 & 58.3 \pm 7.3 & 0.995 \\ & 57.2 \pm 9.4 & 56.6 \pm 7.8 & 0.804 \\ \text { Sex } & & & \\ \text { Male } & 30(40.0 \%) & 19(38.0 \%) & 0.822 \\ \text { Female } & 45(60.0 \%) & 31(62.0 \%) & 0.822 \\ & & & \\ \text { BMI (kg/m }) & 26.0 \pm 5.1 & 21.9 \pm 1.6 & 0.000^{*} \\ <18.5 & 6(8.0 \%) & 0(0.0 \%) & 0.080 \\ 18.5-24.9 & 30(40.0 \%) & 48(96.0 \%) & 0.000^{*} \\ 25-29.9 & 27(36.0 \%) & 2(4.0 \%) & 0.000^{*} \\ 30-34.9 & 8(10.7 \%) & 0(0.0 \%) & 0.021^{*} \\ 35-39.9 & 3(4.0 \%) & 0(0.0 \%) & 0.274 \\ >40 & 1(1.3 \%) & 0(0.0 \%) & 1.000\end{array}$

Waist circum-ference $(\mathrm{cm})$

$\begin{array}{llll}\text { Male } & 95.3 \pm 7.2 & 92.8 \pm 2.48 & 0.162 \\ \text { Female } & 92.5 \pm 1.0 & 81.5 \pm 2.7 & 0.000^{*} \\ \text { SBP }(\mathbf{m m H g}) & 144.0 \pm 12.2 & 120.2 \pm 9.1 & 0.000^{*} \\ \text { DBP }(\mathbf{m m H g}) & 87.1 \pm 8.0 & 79.8 \pm 8.2 & 0.000^{*}\end{array}$

$\mathrm{BMI}=$ Body Mass Index, DBP = Diastolic Blood Pressure, $\mathrm{SBP}=$ Systolic Blood Pressure

\begin{tabular}{|c|c|c|c|}
\hline Parameters & Patients & Controls & $p$-value \\
\hline FBG (mmol/L) & $9.3 \pm 2.4$ & $4.5 \pm 1.0$ & $0.000^{*}$ \\
\hline $\operatorname{CRP}(\mu \mathrm{g} / \mathrm{mL})$ & $2.5 \pm 0.5$ & $1.5 \pm 0.4$ & $0.000^{*}$ \\
\hline $\begin{array}{l}\text { Total cholesterol } \\
\text { (mmol/L) }\end{array}$ & $5.7 \pm 1.3$ & $3.9 \pm 1.2$ & $0.000^{*}$ \\
\hline $\begin{array}{l}\text { LDL cholesterol } \\
(\mathrm{mmol} / \mathrm{L}\end{array}$ & $4.0 \pm 0.7$ & $2.1 \pm 0.4$ & $0.000^{*}$ \\
\hline $\begin{array}{l}\text { HDL cholesterol } \\
\text { (mmol/L) }\end{array}$ & $0.9 \pm 0.2$ & $1.8 \pm 0.2$ & $0.000^{*}$ \\
\hline $\begin{array}{l}\text { Triglycerides } \\
\text { (Mmol/L) }\end{array}$ & $2.3 \pm 0.5$ & $1.4 \pm 0.2$ & $0.000^{*}$ \\
\hline $\begin{array}{l}\text { Serum sodium } \\
\text { (mmol/L) }\end{array}$ & $134.6 \pm 3.2$ & $137.1 \pm 3.5$ & $0.000^{*}$ \\
\hline $\begin{array}{l}\text { Serum potassium } \\
\text { (mmol/L) }\end{array}$ & $3.9 \pm 4.2$ & $4.1 \pm 4.9$ & 0.793 \\
\hline $\begin{array}{l}\text { Serum bicarbonate } \\
\text { (mmol/L) }\end{array}$ & $22.8 \pm 2.7$ & $24.5 \pm 2.4$ & $0.000^{*}$ \\
\hline $\begin{array}{l}\text { Serum urea } \\
(\mathrm{mmol} / \mathrm{L})\end{array}$ & $5.3 \pm 6.6$ & $3.6 \pm 0.6$ & 0.075 \\
\hline Serum creatinine & $90.6 \pm 37.5$ & $58.2 \pm 8.5$ & $0.000^{*}$ \\
\hline
\end{tabular}

FBG $=$ Fasting Blood Glucose, $C R P=C$ - reactive protein, $L D L=$ Low Density Lipoprotein, HDL = High Density Lipoprotein, GFR = Glomerular Filtration Rate, * $=$ Significant at $p<0.05$

Table II Comparison of CRP levels between hypertensivediabetic and normotensive-diabetic

\begin{tabular}{llll}
\hline Parameter & $\begin{array}{l}\text { Hypertensive-diabetic } \\
\mathrm{N}=52\end{array}$ & $\begin{array}{l}\text { Normotensive-diabetic } \\
\mathrm{N}=23\end{array}$ & P-value \\
\hline CRP & $2.51 \pm 0.53$ & $2.54 \pm 0.44$ & 0.823
\end{tabular}

$\mathrm{CRP}=\mathrm{C}-$ reactive protein

Table IV Correlation between CRP and systolic blood pressure, diastolic blood pressure, body mass index and fasting blood glucose in the study patients.

$\begin{array}{llc}\text { Parameters } & \text { Spearman correlation Coefficient }(\mathrm{r}) & \begin{array}{c}\text { P-value } \\ \text { SBP }(\mathrm{mmHg})\end{array} \\ \text { DBP }(\mathrm{mmHg}) & 0.667 & 0.000^{*} \\ \text { BMI }\left(\mathrm{kg} / \mathrm{m}^{2}\right) & 0.438 & 0.000^{*} \\ \text { FBG }(\mathrm{mmol} / \mathrm{L}) & 0.942 & 0.000^{*} \\ & 0.656 & 0.000^{*}\end{array}$

$\mathrm{BMI}=$ Body Mass Index, DBP $=$ Diastolic Blood Pressure, $\mathrm{SBP}=$ Systolic Blood Pressure, $\mathrm{FBG}=$ Fasting Blood Glucose

Table V Correlation between CRP and systolic blood pressure, diastolic blood pressure body mass index and fasting blood glucose among controls.

$\begin{array}{lll}\text { Parameters } & \text { Spearman correlation coefficient }(\mathrm{r}) & \text { P-value } \\ \text { SBP }(\mathrm{mmHg}) & 0.738 & 0.000^{*} \\ \text { DBP }(\mathrm{mmHg}) & 0.686 & 0.000^{*} \\ \text { BMI }\left(\mathrm{kg} / \mathrm{m}^{2}\right) & 0.893 & 0.000^{*} \\ \text { FBG }(\mathrm{mmol} / \mathrm{L}) & 0.551 & 0.000^{*}\end{array}$

$\mathrm{BMI}=$ Body Mass Index, DBP = Diastolic Blood Pressure, SBP = Systolic Blood Pressure, $\mathrm{FBG}=$ Fasting Blood Glucose 
Table VI Correlation between CRP and duration of hypertension and diabetes in the study patients

Parameters

Duration of hypertension

Spearman correlation coefficient $(r)$

0.135

P Value

Duration of diabetes

0.039

0.251

0.739

Table VII Multiple regression analysis between CRP and body mass index, systolic blood pressure, diastolic blood pressure and fasting blood glucose among study patients.

$\begin{array}{lll}\text { Parameters } & \text { Beta value } & \text { P-value } \\ \text { BMI }\left(\mathrm{kg} / \mathrm{m}^{2}\right) & 0.642 & 0.000^{*} \\ \text { SBP }(\mathrm{mmHg}) & 0.409 & 0.000^{*} \\ \text { DBP }(\mathrm{mmHg}) & 0.162 & 0.032^{*} \\ \text { FBG }(\mathrm{mmol} / \mathrm{L}) & 0.119 & 0.036^{*}\end{array}$

$\mathrm{BMI}=$ Body Mass Index, $\mathrm{DBP}=$ Diastolic Blood Pressure, $\mathrm{SBP}=$ Systolic Blood Pressure, FBG = Fasting Blood Glucose

Table VIII Multiple regression analysis between CRP and body mass index, systolic blood pressure, diastolic blood pressure and fasting blood glucose among controls.

$\begin{array}{lll}\text { Parameters } & \text { Beta value } & \text { P-value } \\ \text { BMI }\left(\mathrm{kg} / \mathrm{m}^{2}\right) & 0.602 & 0.000^{*} \\ \text { SBP }(\mathrm{mmHg}) & 0.765 & 0.001^{*} \\ \text { DBP }(\mathrm{mmHg}) & 0.689 & 0.001^{*} \\ \text { FBG }(\mathrm{mmol} / \mathrm{L}) & 0.375 & 0.000^{*}\end{array}$

$\mathrm{BMI}=$ Body Mass Index, DBP = Diastolic Blood Pressure, SBP $=$ Systolic Blood Pressure, $\mathrm{FBG}=$ Fasting Blood Glucose

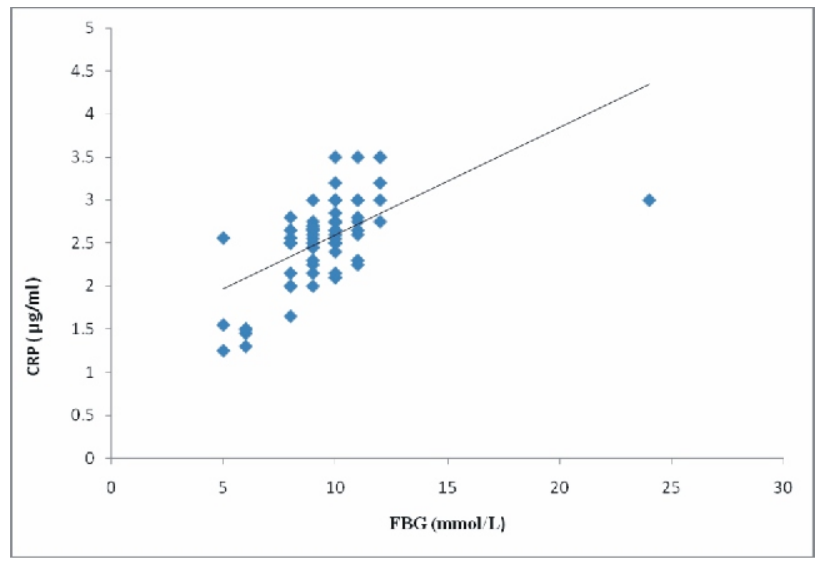

Fig 1 Graphical presentation of correlation between CRP and FBG among patients

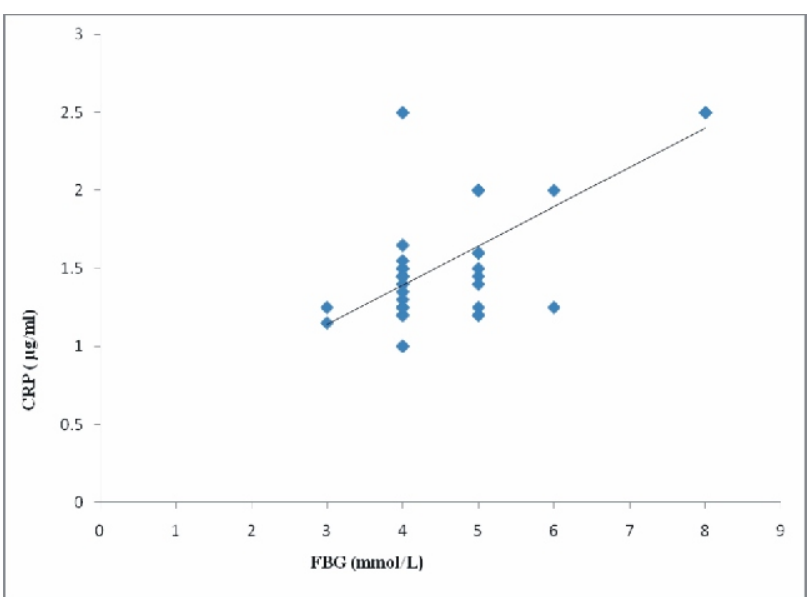

Fig 2 Graphical presentation of correlation between CRP and FBG among controls CRP = C-Reactive Protein, FBG = Fasting Blood Glucose

\section{Discussion}

This cross-sectional study of CRP in Nigerians with type II diabetes mellitus with or without hypertension showed that CRP levels are significantly higher in diabetic than controls. Similarly, there was a positive and significant correlation between CRP levels and FBG. Ford ${ }^{14}$ had previously reported a similar result, though in his study he used glycated haemoglobin to determine the level of glycaemic control in those with diabetes. This study is limited by lack of facilities to test for glycated haemoglobin. The pathophysiologic mechanisms for the elevated CRP in diabetic is linked to the toxic effects of hyperglycaemia on vascular endothelium, increased oxidative stress and the associated generation of free radicals which is injurious to vascular endothelium and triggers inflammation and cytokines release (interleukin 6 , tumour necrosis factor alpha). These cytokines in turn stimulate the synthesis and release of CRP from the liver. ${ }^{15 \text { and } 16}$

The study also showed a positive and significant correlation between CRP and systolic, as well as diastolic blood pressure. However, there was no significant difference in the serum CRP levels between hypertensive-diabetic and normotensive-diabetic. This result is consistent with what was previously reported by other workers. ${ }^{17,18}$ Similarly, there was no significant correlation between the duration of hypertension and diabetes with CRP among the study patients. This suggests that good glycaemic and blood pressure control are associated with lower serum CRP levels than the absolute duration of hypertension or diabetes. The link between hypertension and CRP was thought to be mediated via angiotensin II. Angiotensin II has, in addition to potent vasoconstricting effect, a proinflammatory effect and CRP has been found to up regulate angiotensin I receptor $\mathrm{mRNA}$ and increase the number of angiotensin I receptor binding sites in vascular smooth muscle cells. Angiotensin I receptor is a key atherosclerotic switch facilitating angiotensin-IIinduced reactive oxygen species production, vascular smooth muscle cell migration, proliferation, and vascular remodelling. ${ }^{19}$

Lipid abnormalities occur frequently in diabetic, and in this study it was observed that HDL cholesterol level was significantly lower in patients compared to controls. On the other hand, serum total cholesterol, triglycerides and LDL cholesterol levels were significantly higher in patients compared to controls, this result is similar to what was reported by Bruno et al. ${ }^{20}$ The underlying pathogenesis and the interrelationships between diabetes mellitus and lipid abnormalities have not been 
completely elucidated. However, insulin resistance has been hypothesized to be the common underlying pathogenic mechanism. ${ }^{21}$

\section{Conclusion}

This study showed that diabetics have significantly higher serum C-reactive protein compared to the apparently controls. Also there was a positive and significant correlation between C-reactive protein and fasting blood glucose among both patients and controls.

\section{References}

1 Macy EM, Hayes TE, and Tracy RP. Variability in the measurement of C-reactive protein in healthy subjects. Implication for reference interval and epidemiological applications. Clin Chem 1997; 43:52-58.

2 U.S Biological C-reactive protein, human bioAssay ${ }^{\mathrm{TM}}$ ELISA kit. Catalogue No-C7907-01 .Swampscott, Massachusetts 01907

3 Soinio M, Marniemi J, Laasko M, Letho S, Ronnemaa T. High sensitivity C-reactive protein and coronary heart disease mortality in patients with type II diabetes. A 7-year follow up U.S study. Diabetes Care 2006; 29:329-333.

4 Albert MA, Robert J, Glynn RJ, and Ridker PM. Plasma concentration of $\mathrm{C}$-reactive protein and the calculated Framingham coronary heart disease risk score. Circulation 2003; 108:161165.

5 Mcolhoun H, Schalkwijk C, Rubens MB, Stehouwer Coen DA. C-reactive protein in type I diabetes and its relation to coronary calcification. Diabetes Care 2002; 25:1813-1817.

6 Lagrand WK, Visser CA, Hermens WT, Niessen Hans WM, Verheugt Freek WA. C - reactive protein as a Cardiovascular Risk Factor. More than Epiphenomenon. Circulation 1999; 100:96-102.

7 Kannel WB, McGee DL. Diabetes and cardiovascular disease. The Framingham study. JAMA 1979; 241:20352038.

8 Stamler J, Vaccaro O, Neaton JD, Wentworth D. Diabetes, other risk factors, and 12-year cardiovascular mortality for men screened in the Multiple Risk Factor Intervention Trial. Diabetes Care 1993; 16:434-444.

9 Executive summary of the third report of the National Cholesterol Education Program (NCEP) Expert panel on detection, evaluation and treatment of high blood cholesterol in adults (Adult Treatment Panel III). JAMA 2001; 285:24862497.

10 Haffner S, Letho S, Ronnemaa T, Pyorala K, and
Laasko M. Mortality from coronary heart disease in subjects with type II diabetes and in non diabetic subjects with and without prior myocardial infarction. N Engl J Med 1998; 339:229-234.

11 Steinberg HO, Paradisi G, Cronin J, et al. Type II diabetes abrogates sex difference in endothelial function in pre-menopausal women. Circulation 2000; 101:2040-2046.

12 Tery CM, Callahan KS: Protein kinase C regulates cytokineinduce tissue factor transcription and procoagulant activity in human endothelial cells. Clin Med 1996; 127:81-93.

13 Todd HR and Richard WL. Increased incidence of coronary atherosclerosis in type II diabetes mellitus: Mechanism and management. Ann intern Med 2003; 139:824-834.

14 Ford ES. Body mass index, Diabetes, and Creactive protein among $U$.S adults. Diabetes care 1999; 22:1971-1977.

15 Williams SB, Goldfine AB, Timimi FK, et al. Acute hyperglycaemia attenuate endothelium dependent vasodilatation in humans in vivo. Circulation 1998; 97:16951701.

16 Guzik TJ, Mussa S, Gastaldi D, et al. Mechanism of increased super oxide production in human diabetes mellitus: Role of NAD (P) H oxide synthase. Circulation 2002; 105:1656-1662.

17 Sesso HD, Buring JE, Rifai N, et al. C-reactive protein and the risk of developing hypertension. JAMA 2003; 290:2945-2951.

18 Smith GD, Lawlor DA, Harbord R, Timpson N, et al. Association of C-Reactive Protein with Blood Pressure and Hypertension: Life course confounding and Mendelian Randomization Test of Casualty. Arteriosclerosis thromb vasc biol 2005; 25:1051-1056.

19 Nickenig G, Harrison DG. The AT1-type angiotensin receptor in oxidative stress and atherogenesis. Circulation 2002;105:393-396.

20 Bruno G, Merletti F, Biggeri A, Bargero G, Ferrero S. Metabolic Syndrome as a Predictor of All-Cause and Cardiovascular Mortality in Type 2 Diabetes. Diabetes Care 2004; $27: 2689-2694$.

21 Reaven GM. Role of insulin resistance in human disease. Diabetes 1988; 37:1595-1607. 